\title{
Cloning v. clowning
}

\section{Davor Solter ${ }^{1}$}

Max-Planck Institute of Immunobiology, 79108 Freiburg, Germany
Q. What is cloning?

A. In scientific terms, it is a procedure by which a theoretically infinite number of genetically identical organisms emerge, one at a time, from a Volkswagen Beetle.

Q. No, that's "clowning."

A. Whoops!

Dave Barry: Cloning or Clowning? International Herald Tribune, December 29-30, 2001

Cloning in all of its aspects has captured the imagination of scientists and the general public alike; the issue has engendered considerable controversy and violently opposing opinions. As witnessed during recent hearings held by the National Academy of Sciences (NAS), the safety of human reproductive cloning, not to mention the legal, moral, ethical, or theological implications, can provoke rather strong statements and apparently irreconcilable differences. The majority of scientists argued that at the present time cloning is not safe due to stochastic errors in genome reprogramming. They also presented a limited number of examples (see below) of incorrectly expressed imprinted and nonimprinted genes in clones derived by the transfer of nuclei from somatic and embryonic stem cells. Clowners-excuse me-cloners who vigorously advocated the need for human reproductive cloning (as an ultimate tool in the fight against infertility) claimed that they could check for the correct expression of these genes and use only those embryos that passed such tests. These reproductive cloning advocates apparently failed to realize that misreprogrammed genes are like cockroaches-where you see one there are likely to be many more under the surface. It became clear during this hearing that the would-be human cloners were not convinced by the calls for prudence and are determined to proceed with their plans to clone humans. While the would-be human cloners may have been dismissed by the rest of the panel, they were certainly able to transmit their message via the media to the general public and convince the latter that they know what they are doing, that they are careful and responsible scientists and as such are fully justified in proceeding with human cloning regardless of the risks. One can hope that re-

${ }^{1}$ E-MAIL solter@immunbio.mpg.de; FAX 49-761-5108-569. Article and publication are at http://www.genesdev.org/cgi/doi/10.1101/ gad.998302. ports, like the one published in this issue of Genes \& Development in which Boiani et al. (2002) examine the expression of Oct4 in cloned embryos, will emphasize the futility of any attempt, at present, to select "normal" from "abnormal" clones.

\section{Oct4 and its role in development and pluripotency}

The transcription factor variously known as Oct-3, Oct4 , and Oct-3/4 is a very important molecule and, as such, has had a rather eventful history. It was discovered in the early nineties almost simultaneously by (in order of appearance) Okamoto et al. (1990), Schöler et al. (1990), and Rosner et al. (1990). The first and last groups called the gene Oct-3 and the second group named it Oct-4. Subsequently others, not willing to take risks, came up with the moniker Oct-3/4 and the apparently haphazard usage of dashes further confused the matter. The gene coding for this transcription factor is, through the wisdom of some nomenclature committee, now known (or unknown) as Pou5f1. Regardless of its name (for the rest of this article I will call it Oct4 in agreement with Boiani et al. 2002), it was immediately apparent that it most likely plays an important role in development. Initial reports described the expression of Oct4 in mouse preimplantation embryos, in the ectoderm of the gastrula (but not in other germ layers), and in primordial germ cells (PGCs) as well as in embryonic stem (ES) cells but not in their differentiated derivatives (Okamoto et al. 1990; Rosner et al. 1990; Schöler et al. 1990). These results suggested that Oct4 may be uniquely expressed in totipotent embryonal cells (Yeom et al. 1996) and that it either represents a specific marker of totipotency or may actually be instrumental in imposing totipotency (for review, see Pesce et al. 1998; Pesce and Schöler 2001).

The elucidation of the function of Oct4 was not an entirely smooth process. Oct4 is expressed in ovulated oocytes, thus implying an early role for maternal mRNA and/or protein. In order to check this possibility, Rosner et al. (1991) injected into fertilized mouse eggs either Oct4-antisense oligonucleotides or double-stranded DNA containing the octamer motif (to which Oct4 binds). Both resulted in developmental arrest at the onecell stage. These-for that time-rather spectacular (early days of antisense RNA) and difficult-to-explain results were later revealed as being incorrect and retracted (Rosner et al. 1992). Rather a long period of silence ensued but finally, using gene targeting, the role of Oct4 in 
development was revealed (Nichols et al. 1998). Oct4 null embryos (derived from heterozygous matings and thus possessing maternal Oct4 mRNA and protein) develop to blastocyst but fail after implantation. Analysis in vitro demonstrated that the blastocyst outgrowths of such embryos contain only trophoblastic giant cells and no inner cell mass (ICM) derivatives. Additional experiments demonstrated that ES cells devoid of Oct4 cannot be derived, and together these results suggested that Oct4 is indispensable for the maintenance and proliferation of pluripotent stem cells (Nichols et al. 1998). Obviously the function of Oct4 in oocytes and in PGCs could not be addressed by these experiments and these topics still await experimental clarification.

These results are of obvious significance for the overall understanding of the function of Oct4 in development, but two additional sets of data are even more important for our current discussions. Using immunohistochemistry Palmieri et al. (1994) demonstrated that, as expected, Oct4 is absent from trophectodermal cells at the blastocyst stage. It is, however, present in the cells of ICM and the expression level was apparently higher in primitive endodermal cells than in the cells destined to give rise to the epiblast. These observations were recently expanded by the work of Niwa et al. (2000). Using ingenious genetic manipulations these authors managed to precisely control the level of Oct4 expression in ES cells and to follow the corresponding changes in the phenotype. The ES cell phenotype was maintained when a relative level of Oct 4 expression of 1.0 was present. As the level decreased to below 0.5 , the cells changed to the trophectodermal phenotype (with a corresponding change in molecular markers). In contrast, an Oct4 expression level of 1.5 or higher resulted in a phenotype corresponding to the primitive endoderm and an appropriate switch in molecular markers again accompanied the change. These results indicate that Oct4 is a master regulator of the pluripotent state and they reveal the crucial role of the correct quantitative expression of essential transcription factors in determining cell fate (Stewart 2000). With this background in mind, we can now turn to the results presented by Boiani et al. (2002) and examine their significance within the context of the current debate on human cloning.

\section{Oct4 in cloned embryos}

Boiani and coworkers (2002) produced and examined cloned embryos derived by transferring the nuclei from cumulus cells or fetal germ cells into enucleated oocytes. In order to visualize Oct4 expression, they either used nuclei from mice carrying a transgene in which expression of green fluorescent protein (GFP) is under the control of the Oct4 promoter or they directly analyzed the embryos for the presence of Oct4 mRNA. Development of the cloned embryos was comparable to that observed by other investigators, that is, the majority of clones failed to reach the blastocyst stage and of those that did, only a few developed to term. However, temporal expression of Oct4-GFP was observed in the ma- jority of surviving cumulus clones at the appropriate time in development. The authors (Boiani et al. 2002) then examined the pattern of Oct4 expression in cloned blastocysts. While the vast majority of control embryos expressed Oct4 exclusively in ICM, only $34 \%$ of cloned embryos showed this pattern and the majority (54\%) expressed Oct4 both in ICM and trophectoderm. In addition, they observed an irregular pattern of expression in cloned embryos with some cells of the ICM being positive and some negative and the overall level of expression in the clones was lower than in the control embryos. Moreover, when they examined the outgrowth of cloned blastocysts, half of them did not contain cells expressing Oct4, whereas all control outgrowths did. In summary, these results demonstrate that reprogramming of Oct4 leading to correct temporal and spatial expression occurs rarely in cloned embryos and suggest that the failure of Oct4 expression in ICM could be one of the major causes of the developmental failure of cloned embryos.

\section{Oct4 and the debate on the safety of cloning}

How do these results impact on the issues raised at the beginning of this article, that is, is cloning safe and can it be made safe by analyzing cloned embryos at the blastocyst stage and implanting only those with correct gene expression?

When one examines all reported cases, to date, of cloning using adult cells as nuclear donors, it becomes obvious that cloning is extremely inefficient (Solter 2000). Only $\sim 1 \%$ of manipulated eggs develops to birth and a significant portion of newborn clones die immediately or soon after birth. Failure of reprogramming, the extent of which is probably unique for each individual clone, has been considered to be the most likely cause (Solter 1999) and several recent reports directly address this issue as well as the issue of the phenotypic normalcy of clones. Considering the small number of cases examined, it is not surprising that the results are somewhat controversial. The absence of the correct expression of imprinted genes was observed in fetuses and placentas following cloning from ES cells (Humpherys et al. 2001; Rideout et al. 2001) but only in placentas following cloning from cumulus, Sertoli, and fibroblast cells (Inoue et al. 2002). The report of normal and healthy cloned cattle (Lanza et al. 2001) was soon followed by reports describing obesity (Tamashiro et al. 2002) and early death due to pneumonia and liver failure (Ogonuki et al. 2002) in cloned mice. It may be too soon to try to decide whether normal clones could exist and at what frequency. Besides the very small number of clones examined, it may be too early for some of the clones to show the phenotype. Short-lived mice may display the detrimental consequence of cloning sooner than long-lived cattle, as the recent joint problem observed in Dolly, the oldest living clone, illustrates (Williams 2002).

Considering the strong possibility that any clone will sooner or later display some abnormality, prudence may suggest that the time is not yet ripe for the cloning of 
humans for reproductive purposes. Proponents may argue that the majority (if not all) of conventionally produced humans are not perfect and will sooner or later show such imperfection, so what is the difference? Moreover they would argue that they could analyze the cloned embryos for the expression of genes and use only those whose gene expression is correct. The futility of this argument was considerably strengthened (if indeed strengthening was necessary) by the report of Boiani et al. (2002). Their results clearly show that it is impossible to check clones for the qualitative (correct spatial) and quantitative (correct levels within the embryo) expression of a crucial gene and yet still have the clone available to implant. While the question of the normalcy of any clone (Wilmut 2002) remains open, it may be sensible to refrain from cloning humans (Jaenisch and Wilmut 2001) rather than risk a significant public outcry against science and scientists that would inevitably follow the birth of the first abnormal clone.

Would such a cloning embargo (preferably voluntary) harm anybody? Proponents of reproductive cloning claim that infertile couples yearning for perpetuation of their own genetic material or bereaved parents who believe that humanity needs the unique genetic combination represented by their lost child also deserve consideration. They probably do, and I would be completely sympathetic to their freedom of choice if I could believe that their chances are reasonable and if I could ignore the negative consequences of failures.

The other group which will be disappointed if and when we decide to shelve both the attempts to clone humans and the discussions thereof are those who Jonathan Swift called "the tribe of answerers, considerers, observers, reflecters, detecters, remarkers" and whom we know as talking heads. They have been extremely busy pronouncing on and confusing the issue, which is not surprising as they certainly possess-if I may quote the famous Dean of St. Patrick's once again"this quality (that springs) from a very common infirmity of human nature, inclining us to be more curious and conceited in matters where we have least concern, and for which we are least adapted either by study or nature." Their loss could easily be our gain as anybody reading the transcripts of the President's Council on Bioethics (for sturdy individuals with a great deal of free time the Web address is http://www.bioethics.gov) can ascertain. It is interesting to note that if the Council follows the direction of their discussion to its logical end, they will end up approving reproductive and banning therapeutic cloning.

There is one final issue raised by the Boiani et al. (2002) report. So far we have considered the problems of cloning as arising entirely from the failure of reprogramming, and this may be for the large part correct. There are, however, technical issues involved in cloning, and the effects of the many and varied manipulations a cloned embryo undergoes should not be ignored (Solter 2000; Perry and Wakayama 2002). As a byproduct of experiments aimed at analyzing cloned embryos, researchers started to use controls that they did not generally use before. In order to assess the effect of the technical aspects of cloning they are increasingly using embryos cultured in vitro and embryos produced by intracytoplasmic sperm injection (ICSI) as controls. It is now becoming apparent that these procedures are not innocuous, for example, in vitro embryo-manipulated controls also displayed the obesity phenotype though not as strong as cloned mice (Tamashiro et al. 2002). The embryos fertilized in vitro (IVF) and the ICSI embryos used as controls in Boiani et al. (2002) showed a significantly increased misexpression of Oct4 at the blastocyst stage, though the frequency of misexpression was not nearly as high as in the clones. IVF, ICSI, exchange of cytoplasm between oocytes and obviously in vitro culture are routinely used in human reproductive medicine. Considering that the effect of these procedures was never systematically examined in a long-term longitudinal study, there is cause for apprehension. In view of the fact that the oldest human "test-tube babies" are now in their twenties, it may be a good idea to initiate a detailed analysis of a large cohort and to have these results available before we move into even more exotic areas of human reproduction.

\section{Acknowledgments}

My apologies to Dave Barry for making free use of his title. Jonathan Swift citations are from Gulliver's Travels, pp. 206 and 342, Penguin English Library, Penguin Books, Middlesex, 1981.

\section{References}

Boiani, M., Eckardt, S., Schöler, H.R., and McLaughlin, K.J. 2002. Oct4 distribution and level in mouse clones: consequences for pluripotency. Genes Dev. 16: 1209-1219 (this issue).

Humpherys, D., Eggan, K., Akutsu, H., Hochedlinger, K., Rideout III, W.M., Biniszkiewicz, D., Yanagimachi, R., and Jaenisch, R. 2001. Epigenetic instability in ES cells and cloned mice. Science 293: 95-97.

Inoue, K., Kohda, T., Lee, J., Ogonuki, N., Mochida, K., Noguchi, Y., Tanemura, K., Kaneko-Ishino, T., Ishino, F., and Ogura, A. 2002. Faithful expression of imprinted genes in cloned mice. Science 295: 297.

Jaenisch, R. and Wilmut, I. 2001. Don't clone humans! Science 291: 2552.

Lanza, R.P., Cibelli, J.B., Faber, D., Sweeney, R.W., Henderson, B., Nevala, W., West, M.D., and Wettstein, P.J. 2001. Cloned cattle can be healthy and normal. Science 294: 1893-1894.

Nichols, J., Zevnik, B., Anastassiadis, K., Niwa, H., Klewe-Nebenius, D., Chambers, I., Schöler, H., and Smith, A. 1998. Formation of pluripotent stem cells in the mammalian embryo depends on the POU transcription factor Oct4. Cell 95: 379-391.

Niwa, H., Miyazaki, J.-i., and Smith, A.G. 2000. Quantitative expression of Oct-3/4 defines differentiation, dedifferentiation or self-renewal of ES cells. Nat. Genet. 24: 372-376.

Ogonuki, N., Inoue, K., Yamamoto, Y., Noguchi, Y., Tanemura, K., Suzuki, O., Nakayama, H., Doi, K., Ohtomo, Y., Satoh, M., et al. 2002. Early death of mice cloned from somatic cells. Nat. Genet. 30: 253-254.

Okamoto, K., Okazawa, H., Okuda, A., Sakai, M., Muramatsu, M., and Hamada, H. 1990. A novel octamer binding tran- 
scription factor is differentially expressed in mouse embryonic cells. Cell 60: 461-472.

Palmieri, S.L., Peter, W., Hess, H., and Schöler, H.R. 1994. Oct-4 transcription factor is differentially expressed in the mouse embryo during establishment of the first two extraembryonic cell lineages involved in implantation. Dev. Biol. 166: 259-267.

Perry, A.C.F. and Wakayama, T. 2002. Untimely ends and new beginnings in mouse cloning. Nat. Genet. 30: 243-244.

Pesce, M. and Schöler, H.R. 2001. Oct-4: Gatekeeper in the beginnings of mammalian development. Stem Cells 19: 271278

Pesce, M., Gross, M.K., and Schöler, H.R. 1998. In line with our ancestors: Oct-4 and the mammalian germ. BioEssays 20: $722-732$.

Rideout III, W.M., Eggan, K., and Jaenisch, R. 2001. Nuclear cloning and epigenetic reprogramming of the genome. Science 293: 1093-1098.

Rosner, M., Vigano, M.A., Ozato, K., Timmons, P., Poirier, F., Rigby, P., and Staudt, L. 1990. A POU-domain transcription factor in early stem cells and germ cells of the mammalian embryo. Nature 345: 686-692.

Rosner, M., De Santo, R., Arnheiter, H., and Staudt, L. 1991. Oct-3 is a maternal factor required for the first mouse embryonic division. Cell 64: 1103-1110.

Rosner, M., De Santo, R.J., Arnheiter, H., and Staudt, L.M. 1992. Retraction: Oct-3 is a maternal factor required for the first mouse embryonic division. Cell 69: 724.

Schöler, H.R., Ruppert, S., Suzuki, N., Chowdhury, K., and Gruss, P. 1990. New type of POU domain in germ line-specific protein Oct-4. Nature 344: 435-439.

Solter, D. 1999. Cloning and embryonic stem cells: A new era in human biology and medicine. Croat. Med. J. 40: 309-318.

Solter, D. 2000. Mammalian cloning: Advances and limitations. Nat. Rev. Genet. 1: 199-207.

Stewart, C.L. 2000. Oct-4, scene 1: The drama of mouse development. Nat. Genet. 24: 328-330.

Tamashiro, K.L.K., Wakayama, T., Akutsu, H., Yamazaki, Y., Lachey, J.L., Wortman, M.D., Seeley, R.J., D'Alessio, D.A., Woods, S.C., Yanagimachi, R., et al. 2002. Cloned mice have an obese phenotype not transmitted to their offspring. Nat. Med. 8: 262-267.

Williams, N. 2002. Dolly clouds cloning hopes. Curr. Biol. 12: R79-R80.

Wilmut, I. 2002. Are there any normal cloned mammals? Nat. Med. 8: 215-216.

Yeom, Y.I., Fuhrmann, G., Ovitt, C.E., Brehm, A., Ohbo, K., Gross, M., Hübner, K., and Schöler, H.R. 1996. Germline regulatory element of Oct-4 specific for the totipotent cycle of embryonal cells. Development 122: 881-894. 


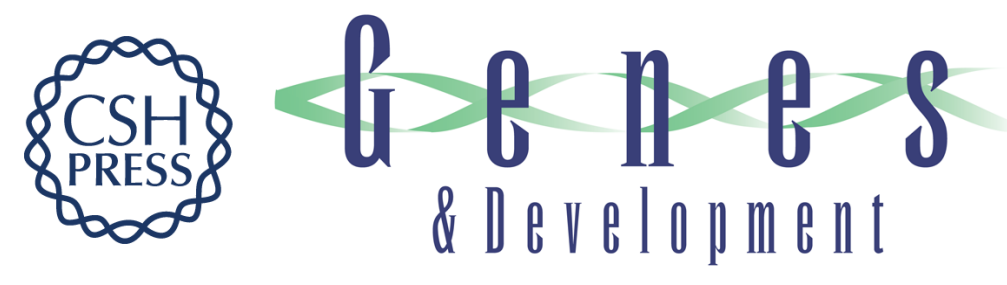

\section{Cloning v. clowning}

Davor Solter

Genes Dev. 2002, 16:

Access the most recent version at doi:10.1101/gad.998302

References This article cites 25 articles, 7 of which can be accessed free at: http://genesdev.cshlp.org/content/16/10/1163.full.html\#ref-list-1

License

Email Alerting Receive free email alerts when new articles cite this article - sign up in the box at the top Service right corner of the article or click here.

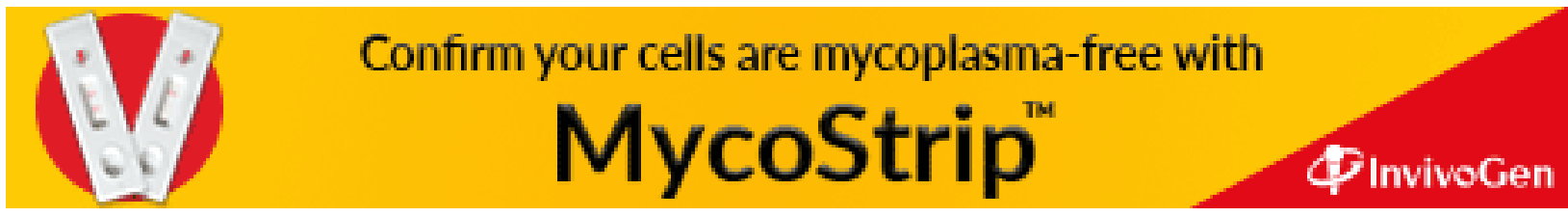

